\title{
Labour
}

Journal of Canadian Labour Studies

Le Travail

Revue d'Études Ouvrières Canadiennes

\section{Interrogating the Relationship Between Bargaining Structures and Bargaining Outcomes for Contract Academic Faculty in Ontario}

\section{Stephanie Ross, Larry Savage et James Watson}

Volume 86, automne 2020

URI : https://id.erudit.org/iderudit/1074471ar

DOI : https://doi.org/10.1353/1lt.2020.0035

Aller au sommaire du numéro

Éditeur(s)

Canadian Committee on Labour History

ISSN

0700-3862 (imprimé)

1911-4842 (numérique)

Découvrir la revue

Citer cet article

Ross, S., Savage, L. \& Watson, J. (2020). Interrogating the Relationship Between Bargaining Structures and Bargaining Outcomes for Contract Academic Faculty in Ontario. Labour / Le Travail, 86, 9-43. https://doi.org/10.1353/lt.2020.0035
Résumé de l'article

Cet article utilise des études de cas de trois universités comparables basées en Ontario pour explorer la relation entre les structures des unités de négociation et les résultats de la négociation collective pour les professeurs d'université à contrat syndiqués. L'article décrit le réseau complexe des structures d'unités de négociation et des relations intersyndicales ou associatives dans les universités de l'Ontario et utilise des données quantitatives et qualitatives pour illustrer comment différentes structures influencent les débats internes sur les professeurs d'université à contrat, les priorités de négociation et les stratégies de négociation collective. Les auteurs concluent que les structures des unités de négociation ont moins d'impact que ne le supposent les praticiens et que le succès à la table de négociation des professeurs d'université à contrat dépend d'un large éventail de facteurs plutôt que d'une structure particulière. 


\title{
Interrogating the Relationship Between Bargaining Structures and Bargaining Outcomes for Contract Academic Faculty in Ontario
}

\author{
Stephanie Ross, McMaster University \\ Larry Savage, Brock University \\ James Watson, McMaster University
}

AcCording to A 2018 Report published by the Canadian Centre for Policy Alternatives, over half of university faculty appointments in Canada are filled by contract academic faculty whose employment is generally precarious, parttime, comparatively low paid, and absent access to the same level of academic freedom and collegial decision-making as traditional university faculty. ${ }^{1}$ In an effort to improve their terms and conditions of work, sessional contract academic faculty at virtually every Ontario university have sought and secured union certification. ${ }^{2}$ However, given the decentralized nature of labour rela-

1. Erika Shaker \& Chandra Pasma, Contract U: Contract Faculty Appointments at Canadian Universities (Ottawa: Canadian Centre for Policy Alternatives, 2018), 5; Cynthia C. Field \& Glen A. Jones, A Survey of Sessional Faculty in Ontario Publicly-Funded Universities, Research Report 2016.04 (Toronto: Centre for the Study of Canadian and International Higher Education, OISE-University of Toronto, 2016).

2. Following Field and Jones, we use the term "sessional" to refer to those faculty members who work on a contractual basis as instructors, typically on semester-by-semester contracts. Sessionals are often referred to as "part-time" instructors, both formally and informally, despite the number of hours associated with their contracts. In fact, many work in excess of full-time hours but are still designated "part-time," reflecting their lack of status and relative precarity in the academy. Conversely, tenured, tenure-stream, and contractually limited faculty 
tions in Canada, bargaining unit structures for sessional contract academic faculty differ dramatically across the university sector. Three main structural variations are at play: (1) sessional contract academic faculty and full-time academic faculty at the same university are grouped together in the same union and same bargaining unit for the purposes of collective bargaining; (2) fulltime faculty and sessional contract faculty working at the same university are represented by separate unions or associations; and (3) sessional contract academic faculty and full-time faculty teaching at the same university are represented by the same union but are in separate bargaining units for the purposes of collective bargaining. Given the variety of bargaining structures and the existence of multiple unions or associations on the same campus, it can be unclear who speaks for sessionals, who best represents their interests, and how those interests are understood, framed, and prioritized in collective bargaining. The aim of this research is to explore the link between bargaining unit structures and outcomes for contract academic faculty with a view to determining whether one specific bargaining structure leads to better terms and conditions of work for contract academic faculty hired on a per-course basis.

\section{Context}

As in most Western Democracies, higher education in Ontario, Canada, is undergoing profound neoliberal restructuring, sometimes referred to as the corporatization of universities. We use the term "neoliberal university" to describe the use of market-based practices, criteria, and cultural norms to organize the university and judge the success of its components. Several decades in the making, the neoliberal university is characterized by the growth of precarious and contingent academic workforces, the intensification of work, the expansion of corporate-university linkages, and the growth of a non-academic administrative cadre. ${ }^{3}$ Neoliberal reforms entail a major

appointments are often formally or informally referred to as "full-time." Again, this is less a reflection of the hours of work associated with the job than a statement about the relative security or range of duties beyond teaching associated with the position. While we recognize that the labels "part-time" and "full-time" are imperfect and contested descriptors, we adopt them for practical reasons for the purposes of this research because our interviewees use these terms and they also appear formally in the collective agreements of the three universities used as case studies.

3. Sheila Slaughter \& Gary Rhodes, Academic Capitalism and the New Economy: Markets, State and Higher Education (Baltimore: Johns Hopkins University Press, 2004); Gina Anderson, "Mapping Academic Resistance in the Managerial University," Organization 15, 2 (2008): 251-270; Dan Clawson \& Max Page, The Future of Higher Education (New York: Routledge, 2011); James E. Côté \& Anton L. Allahar, Lowering Higher Education: The Rise of the Corporate University and the Decline of Liberal Education (Toronto: University of Toronto Press, 2011); Benjamin Ginsberg, The Fall of the Faculty: The Rise of the All-Administrative University and Why It Matters (New York: Oxford University Press, 2011); Jonah Butovsky, 
redistribution of power and resources inside universities as well as a shift in internal relations and values. The former is best exemplified by review and prioritization exercises designed to redirect resources toward more revenuegenerating programs. ${ }^{4}$ Externally, neoliberal reforms are driven by state-led austerity and reduced government support for the university sector. Even Peter MacKinnon, a proponent of university commercialization and a fierce critic of faculty unionism, has expressed concern over declining government support for university operating costs - even warning that "if this continues for an extended period of time, it is not hyperbole to speak of the privatization of university education." 5

Because the post-secondary sector is one of the most densely unionized in Canada, unions representing academic workers are central to struggles concerning the defence of public services, the quality of education, and the protection and expansion of secure jobs in universities. ${ }^{6}$ Yet the different class positions and increasing internal stratification of university workers have prompted various categories of faculty to defend their interests in distinct ways and with decidedly different results. ${ }^{7}$ While tenured faculty have managed to weather the storm of neoliberal reform by continuing to secure relatively impressive economic gains, their sessional counterparts have not fared nearly as well. ${ }^{8}$ This disparity is a growing concern because while Canadian

Larry Savage \& Michelle Webber, "Assessing Faculty Attitudes toward Faculty Unions: A Survey of Four Primarily Undergraduate Universities," Working USA: A Journal of Labor and Society 18, 2 (2015): 247-265; Claire Polster \& Janice Newson, A Penny for Your Thoughts: How Corporatization Devalues Teaching, Research, and Public Service in Canada's Universities (Ottawa: Our Schools/Our Selves and the Canadian Centre for Policy Alternatives, 2015); Grace Karram Stephenson, Glen A. Jones, Olivier Bégin-Caouette, Amy Metcalfe \& Arif Toor, Responding to Change, Assessing Difference: A Review of the Literature on Professors at Canadian Universities, CiHE Report 2017.05 (Toronto: Centre for the Study of Canadian and International Higher Education, OISE-University of Toronto, 2017); Stephanie Ross, Larry Savage \& James Watson, "University Teachers and Resistance in the Neoliberal University," Labor Studies Journal, advance online publication, 1 November 2019, https://doi. org/10.1177/0160449X19883342 .

4. Robert Dickeson, Prioritizing Academic Programs and Services: Reallocating Resources to Achieve Strategic Balance, 2nd ed. (San Francisco: Jossey-Bass, 2010); Craig Heron, "Robert Dickeson: Right for Ontario?" (Toronto: Ontario Confederation of University Faculty Associations, n.d.), accessed 10 July 2020, https://ocufa.on.ca/assets/Dickeson-Right-forOntario-Craig-Heron.pdf.

5. Peter MacKinnon, University Leadership and Public Policy in the Twenty-First Century: A President's Perspective (Toronto: University of Toronto Press, 2014), 54.

6. David Dobbie \& Ian Robinson, "Reorganizing Higher Education in the United States and Canada: The Erosion of Tenure and the Unionization of Contingent Faculty," Labor Studies Journal 33, 2 (2008): 117-140.

7. Joe Berry, "Competitive Unionism: Good, Bad, or Indifferent for Contingent Faculty?," Workplace 12 (2005): 56-63.

8. Karen Foster \& Louise Birdsell Bauer, Out of the Shadows: Experiences of Contract Academic 
universities have long relied on contract academic faculty, the number and share of sessional instructors has significantly increased since the 1980 s. $^{9}$

While several scholars have explored issues related to the rise of contract academic faculty in Canada, academic unions and associations do not figure prominently in such studies. ${ }^{10}$ This is surprising given that the collective bargaining process is the main mechanism used to establish terms and conditions of work for contract academic faculty. ${ }^{11}$ The unionization of university faculty in Ontario occurred in three waves. In the 1960s, the Ontario provincial government invested in a massive expansion of post-secondary education, leading to the establishment of several new, primarily undergraduate, universities. By the mid-1970s, however, the era of university expansion was replaced by a period of contraction and instability, prompting faculty at a number of universities to transform their faculty associations into bona fide unions. ${ }^{12}$ In

Staff (Ottawa: Canadian Association of University Teachers, 2018): 26.

9. Helen Breslauer, "Women in the Professoriate: The Case of Multiple Disadvantage," in Cicely Watson, ed., The Professoriate: Occupation in Crisis (Toronto: Ontario Institute for Studies in Education, 1985); Dobbie \& Robinson, "Reorganizing Higher Education"; Linda Muzzin, "How Fares Equity in an Era of Academic Capitalism? The Role of Contingent Faculty," in Adrienne Chan \& Donald Fisher, eds., The Exchange University: Corporatization of Academic Culture (Vancouver: UBC Press, 2008).

10. Carolin Kreber, "Integrating Teaching with Other Aspects of Professorial Work: A Comparison of Experienced and Inexperienced Faculty's Role Conceptualizations," Canadian Journal of Higher Education 30, 3 (2000): 79-113; Indhu Rajagopal, "The Political Economy of Part-Time Academic Work in Canada," Higher Education 18, 3 (1989): 267-285; Rajagopal, Hidden Academics: Contract Faculty in Canadian Universities (Toronto: University of Toronto Press, 2002); Rajagopal, "Tenuous Ties: The Limited-Term Full-Time Faculty in Canadian Universities," Review of Higher Education 28, 1 (2004): 49-75; Korbla P. Puplampu, "The Restructuring of Higher Education and Part-Time Instructors: A Theoretical and Political Analysis of Undergraduate Teaching in Canada," Teaching in Higher Education 9, 2 (2004): 171182; Muzzin, "How Fares Equity?"; Louise Birdsell Bauer, "Permanently Precarious? Contingent Academic Faculty Members, Professional Identity and Institutional Change in Quebec Universities," MA thesis, Concordia University, 2011; Jamie Brownlee, "Contract Faculty in Canada: Using Access to Information Requests to Uncover Hidden Academics in Canadian Universities," Journal of Higher Education 70, 5 (2015): 787-805.

11. Glen A. Jones, "The Horizontal and Vertical Fragmentation of Academic Work and the Challenge for Academic Governance and Leadership," Pacific Education Review 14, 1 (2013): 75-83; Jula Hughes \& David Bell, "Bargaining for Contract Academic Staff at English Canadian Universities," Working USA: The Journal of Labor and Society 18, 3 (2015): 377-394.

12. Craig C. Heron, "From Deference to Defiance: The Evolution of Ontario Faculty Associations," Academic Matters: OCUFA's Journal of Higher Education (Spring-Summer 2015), https://academicmatters.ca/from-deference-to-defiance-the-evolution-of-ontariofaculty-associations/; Michiel Horn, "Unionization and the Canadian University: Historical and Personal Observations," Interchange 25, 1 (1994): 39-48; Sandra Rastin, "Organizing Tactics in a Faculty Unionization Drive at a Canadian University," Labor Studies Journal 25, 2 (2000): 99-119; Larry Savage, Michelle Webber \& Jonah Butovsky, "Organizing the Ivory Tower: The Unionization of the Brock University Faculty Association," Labor Studies Journal 37, 3 (2012): 293-310. 
some cases, like at the University of Windsor (1978), full-time faculty organized together with contract academic faculty into a single bargaining unit, while in other instances, like at York University (1977), full-time faculty and sessional faculty organized separately. This first wave of faculty unionization was followed by a second, smaller wave in the 1980s. This period of early neoliberal restructuring unfolded unevenly but was generally characterized by employers' more aggressive stance in collective bargaining, job cuts, contracting out and privatization, restrictions on the right to strike, and growing use of back-to-work legislation. ${ }^{13}$ These economic pressures prompted several university faculty associations to pursue unionization to defend the immediate employment interests of their members. Finally, a third wave of unionization took place in Ontario in the 1990s, amid deep cuts to the university sector paired with significant intervention in public-sector labour relations. As the twin pressures of austerity and deprofessionalization threatened to roll back working conditions in universities and erode the professional autonomy of academics, faculty associations increasingly looked toward unionization as a tool to combat neoliberal and managerial encroachments on institutions of higher education. ${ }^{14}$ By the late 1990s, both the Canadian Association of University Teachers (CAUT) and the Canadian Union of Public Employees (CUPE) were competing to organize the remaining pockets of non-union contract academic faculty across Canada, with the vast majority opting to join faculty associations affiliated with CAUT. ${ }^{15}$

These waves of faculty unionization reveal a complex dynamic that has helped drive change in the university sector. As in the first and second waves, faculty who pursued union certification as part of the third wave of unionization did so in ways that produced different bargaining structures. Whether for strategic or ideological reasons, many faculty associations deliberately excluded contract academic faculty when forming their unions, while others integrated sessional instructors into their new unions. Thus, sessional contract academic faculty were sometimes paired with full-time professors for the

13. Leo Panitch \& Donald Swartz, From Consent to Coercion: The Assault on Trade Union Freedoms (Toronto: Garamond, 2003); Rastin, "Organizing Tactics," 103.

14. Marc Dixon, Daniel Tope \& Nella Van Dyke, “'The University Works Because We Do': On the Determinants of Campus Labor Organizing in the 1990s," Sociological Perspectives 51, 2 (2008): 375-396.

15. CAUT official, confidential interview, 8 July 2019; former CAUT official, confidential interview, 10 October 2019; former CUPE official, confidential interview, 11 July 2019. CAUT is not a union but rather a federation of both certified and non-certified independent faculty associations and local unions representing faculty in post-secondary institutions. CUPE is, by far, the largest union in Canada, with the vast majority of its members employed in the public sector. While CUPE does not represent any full-time faculty in Canada, it does represent sessional contract academic faculty at several universities in Ontario and across Canada. 
purposes of collective bargaining, while others were forced to organize their own unions, typically as CUPE bargaining units. ${ }^{16}$

Faculty associations' anathema toward CUPE has a long history and played a key role in the growth and development of faculty unionism in Canada. As Michiel Horn, a former CAUT executive member and president of the York University Faculty Association in the early 1970s, observed,

I well remember the dismay I and other members of the [CAUT] executive felt when we learned that some professors at St. Mary's had turned to the Canadian Union of Public Employees for assistance with certification. Several members of the executive, notably the vice-president, Richard Spencer of UBC, and the executive secretary, Donald Savage, argued that we must meet the CUPE challenge with all the means at our disposal. Dick Spencer predicted that if CUPE were successful in organizing the St. Mary's faculty and negotiated a good first contract, several other and larger faculty associations would soon follow the St. Mary's example.

CAUT won the certification battle at St. Mary's. Apparently we benefited from the hostility to unionization of some professors there. Faced with a choice between two unions, one affiliated with CUPE and the other with CAUT, those who did not like unions voted for the latter as the lesser of evils! ${ }^{17}$

CAUT's intervention at St. Mary's University in the early 1970s in opposition to CUPE not only helped to certify the faculty association but also helped to foster a pro-certification culture that encouraged faculty members across the country to view themselves as unaligned with public-sector unionism in general, and in opposition to CUPE specifically. This professional, guild-like, ideological positioning has heavily influenced faculty unionism in Canada for much of its history. ${ }^{18}$ However, the recent acceptance of CUPE sessional contract faculty locals as CAUT affiliates, the creation of the National Union of the Canadian Association of University Teachers (NUCAUT) as a vehicle for faculty unions to join the Canadian Labour Congress, and experiments with campaign-based or mobilization collective bargaining strategies suggest that faculty unions are shedding some of their long-standing ideological baggage. ${ }^{19}$

The way unions are formed shapes their internal cultures and practices, which, in turn, can have a tremendous impact on collective bargaining priorities and strategies. ${ }^{20}$ The existence of multiple kinds of bargaining structures

16. Cynthia Field, Glen A. Jones, Grace Karram Stephenson \& Artur Khoyetsyan, The "Other" University Teachers: Non-full-time Instructors at Ontario Universities (Toronto: Higher Education Quality Council of Ontario, 2014).

17. Horn, "Unionization and the Canadian University," 46.

18. Larry Savage \& Michelle Webber, "The Paradox of Professionalism: Unions of Professionals in the Public Sector," in Stephanie Ross \& Larry Savage, eds., Public Sector Unions in the Age of Austerity (Halifax: Fernwood, 2013), 114-125.

19. Ross, Savage \& Watson, "University Teachers."

20. Stephanie Ross, "The Making of CUPE: Structure, Democracy and Class Formation," PhD diss., York University, 2005. 
in Ontario gives us an excellent opportunity to test empirically whether one structure has helped produce greater advances for contract academic faculty. Ontario is an ideal site for a study on contract academic faculty because it is home to the largest number of universities in Canada, has a good cross-section of differentiated bargaining unit structures, and has one of the highest proportions of contract academic staff in Canada. As of March 2020, all full-time faculty in Ontario are unionized, except for professors at the University of Toronto, McMaster University, the University of Waterloo, and several small colleges associated with universities. However, even these universities do have faculty associations that act as de facto bargaining agents for full-time faculty. Sessional contract academic faculty, on the other hand, are unionized on every campus in the province, with the exception of the University of Waterloo.

While the need for greater research on contract academic faculty is evident given the changing landscape of work in universities, how we understand these changes, their context, and potential solutions requires a theoretical approach that takes seriously both agency and structure as important factors in determining outcomes. Our research is informed by critical institutionalism and the political sociology of trade unions - both interdisciplinary theoretical approaches that focus on the dialectical interplay between institutional structures and social/organizational dynamics over time. ${ }^{21}$ As applied to the subject matter of this article, critical institutionalism views collective bargaining structures and outcomes as inseparable from the broader political and economic forces shaping the post-secondary sector in Ontario. Collective bargaining structures and workers' representative organizations are not created from ideal types. Rather, they are shaped and transformed by the concrete social relations, circumstances, and conflicts they both reflect and reproduce. We take added insight on this point from the work of British industrial relations scholar Richard Hyman, who, in his political sociology of union structure, argues that it "is not a fixed phenomenon but a process, the historical outcome of interdependent but not purposefully integrated strategies of a variety of fragmented employee groups." As such, union structures are the product of the dynamic interaction of "two contradictory forces": that toward "breadth, unity and solidarity" and that toward "parochialism, sectionalism and exclusiveness." While workers are potentially unified by the common experience of having to sell their labour and being subject to managerial authority, they do not do so in exactly the same circumstances. The tendency "to be conscious primarily of [one's] immediate work milieu, ... everyday experiences, ... [and] direct and personal relationships" is reinforced by both ideological "inhibitions" against class consciousness and the enduring effectiveness of strategies based on narrow forms of identification and closed union structures. While maximal unity in a sector may seem to produce more power in the abstract, 
situations that allow for some groups of workers to "monopolise ... islands of advantageous conditions" provide a break on the development of more expansive forms of solidarity. As such, Hyman shows that workers' movements and organizations have always engaged in struggles over definitions of collective interests and purpose and the criteria for inclusion in or exclusion from workers' organization. The result has been "diverse forms of workers' solidarity," indicating "contradictory elements in their consciousness." 22

\section{Methodology}

OUR RESEARCH RELIES on a mixed-methods approach. Our quantitative analysis is based on a combination of data from the Ontario Confederation of University Faculty Associations (OCUFA) and our own research into collective agreement language. We collected and analyzed relevant collective agreements in Ontario universities (see Table 1) to determine whether there are quantifiable patterns of bargaining outcomes for sessionals. We measure advances for sessionals using a Collective Agreement Provision Index (CAPI) (see Table 2) that we developed specifically for this program of research. The index measures job quality in terms of wages, benefits, pension eligibility, institutional research support, access to work (including seniority and right of first refusal), conversion to more permanent positions, contract notice, contract cancellation penalties, infrastructural access, collegial governance, and professional expense accounts. Each CAPI variable score attempts to capture the relative strengths of contract language based on explicitly stated provisions in the sector's collective agreements. ${ }^{23}$

That our measures only encompass provisions that are explicit in collective agreements has two important implications. First, workplace provisions that fall under university policy may be missed. Variables such as institutional research supports, infrastructural access, collegial governance, and certain quasi-contractual benefits may be particularly affected by this choice as they may exist but not be articulated in collective agreements. However, we contend that it is more accurate to focus on the contents of enforceable and legally binding collective agreements, as opposed to voluntarist employer policy, to determine what workers and unions have actually "won." Second, even with provisions secured in a legally binding contract, discrepancies can emerge between "paper" eligibilities and entitlements and what actually occurs in practice. For example, pension plan provisions read in isolation may

22. Richard Hyman, Industrial Relations: A Marxist Introduction (London: MacMillan, 1975), $41-42,46,62-63$.

23. Academic freedom provisions are excluded from the CAPI for the purposes of this analysis. However, given the importance of academic freedom as a workplace right in universities, the authors are engaged in a related study exploring the specific link between academic freedom, unionization, and contract academic faculty. 
Table 1: Cases of and Bargaining Unit Structures for Sessional Contract Academic Faculty

\begin{tabular}{|c|c|}
\hline $\begin{array}{l}\text { Bargaining unit } \\
\text { structure }\end{array}$ & University - Bargaining unit (Contract years) \\
\hline \multirow{4}{*}{$\begin{array}{l}\text { Separate } \\
\text { bargaining faculty } \\
\text { units }\end{array}$} & Algoma - AUFA Contract Instructors (2016-19) \\
\hline & Nipissing - NUFA CASBU (2016-19) \\
\hline & St. Jerome's - SJUASA CAS Unit (2018-21) \\
\hline & Wilfred Laurier - WLUFA CAS Unit (2016-19) \\
\hline \multirow[t]{7}{*}{ All-in faculty units } & Huron - HUCFA (2015-18) \\
\hline & Lakehead - LUFA (2016-20) \\
\hline & Laurentian - LUFA-APPUL (2016-20) \\
\hline & OCAD - OCADFA (2016-19) \\
\hline & Queen's - QUFA (2015-19) \\
\hline & Western - UWOFA (2014-18) \\
\hline & Windsor - WUFA (2017-21) \\
\hline \multirow{11}{*}{$\begin{array}{l}\text { Separate union } \\
\text { units }\end{array}$} & Brock - CUPE 4207 U1 (2016-19) \\
\hline & Carleton - CUPE 4600 U2 (2016-19) \\
\hline & Guelph - CUPE 3913 U2 (2016-19) \\
\hline & King's University College - CUPE 5265 (2015-18) \\
\hline & McMaster - CUPE 3906 U2 (2017-20) \\
\hline & Ottawa - APTPUO (2016-18) \\
\hline & Ryerson - CUPE 3904 U1 (2017-21) \\
\hline & Toronto - CUPE 3902 U3 (2017-21) \\
\hline & Trent - CUPE 3908 U1 (2016-19) \\
\hline & UOIT - PSAC 555 (2017-21) \\
\hline & York - CUPE 3903 U2 (2017-20) \\
\hline
\end{tabular}

demonstrate a relatively low barrier to entry but are usually linked to contract language concerning access to work and minimum work requirements that create additional hurdles. Acknowledging these limitations has, in turn, influenced how each CAPI variable is measured.

Once CAPI scores were calculated for each variable, and for each bargaining unit, the results for each bargaining structure were averaged so that the outcomes could be compared. As previously discussed, bargaining unit structures for sessional contract academic faculty fall into three mutually exclusive categories: all-in faculty associations; separate bargaining unit faculty associations; and separate unions. All of the cases used in the CAPI are listed in 
Table 2: CAPI Variables, Scales, and Measurements

\begin{tabular}{|c|c|}
\hline $\begin{array}{l}\text { Variable } \\
\text { (Level of } \\
\text { measurement) }\end{array}$ & Scale and measurement \\
\hline $\begin{array}{l}\text { Wages }(\mathrm{R}, \\
\text { converted to } \mathrm{O})\end{array}$ & $\begin{array}{l}\text { Score of } 0-5 \text { based on }+/ \text { - standard deviations from the average sector } \\
\text { wage for a half-course equivalent (HCE). Score of } 3 \text { is within } 1+/ \text { - standard } \\
\text { deviation of the average. }\end{array}$ \\
\hline Benefits (O) & $\begin{array}{l}\text { Score of 0-5 based on presence of employer-sponsored provisions for } \\
\text { five most common benefits (healthcare spending accounts, dental, life } \\
\text { insurance, long-term disability, counselling). } \\
\text { Average from latest CAs }\end{array}$ \\
\hline $\begin{array}{l}\text { Pension eligibility } \\
\text { (O) }\end{array}$ & $\begin{array}{l}\text { Score of } 0-5 \text { based on "paper eligibility" - the ease with which sessionals } \\
\text { can enrol in a university-sponsored pension plan. } \\
\text { Average from latest CAs }\end{array}$ \\
\hline $\begin{array}{l}\text { Institutional } \\
\text { research supports } \\
\text { (O) }\end{array}$ & $\begin{array}{l}\text { Score of 0-5 based on presence of the following five research supports: } \\
\text { Support for Applications to Tri-Council Grants; Access to Internal Grant } \\
\text { Competitions; Access to Contract Faculty Research Funds; Access to } \\
\text { Funded Research Leaves; Access to PhD Completion Funds. } \\
\text { Average from latest CAs }\end{array}$ \\
\hline Access to work (0) & $\begin{array}{l}\text { Score of } 0-5 \text { based on seniority provisions; eligibility and entitlement } \\
\text { provisions for incumbency/right of first refusal. } \\
\text { Average from latest CAs }\end{array}$ \\
\hline Conversion (0) & $\begin{array}{l}\text { Score of } 0-5 \text { based on provisions for securing more permanent (non- } \\
\text { sessional) work arrangements. } \\
\text { Average from latest CAs }\end{array}$ \\
\hline Notice (0) & $\begin{array}{l}\text { Score of } 0-5 \text { (quintiles) based on months of notice a contract must be } \\
\text { issued (months before fall semester baseline). }\end{array}$ \\
\hline $\begin{array}{l}\text { Cancellation } \\
\text { penalties }(0)\end{array}$ & $\begin{array}{l}\text { Score of 0-5 (quintiles) based on payment (CAD) if course is cancelled } 1 \\
\text { month, } 1 \text { day before contract starts using HCE overall sector average. }\end{array}$ \\
\hline $\begin{array}{l}\text { Infrastructural } \\
\text { access }(0)\end{array}$ & $\begin{array}{l}\text { Scale of } 0-2 \text { based on access to email, office, and library: no access (0); } \\
\text { contingent access ( } 1 \text {; ; and non-contingent access ( } 2) \text {. } \\
\text { Average from latest CAs }\end{array}$ \\
\hline $\begin{array}{l}\text { Collegial } \\
\text { governance (0) }\end{array}$ & $\begin{array}{l}\text { Score of } 0-2 \text { based on provisions related to representation (voice and/ } \\
\text { or vote) at the senate/board of governors level and faculty/department } \\
\text { councils (or equivalents). } \\
\text { Average from latest CAs }\end{array}$ \\
\hline $\begin{array}{l}\text { Professional } \\
\text { expense fund }(0)\end{array}$ & $\begin{array}{l}\text { Score of } 0-2 \text { based on ease/barriers of eligibility and administrating agents } \\
\text { (management/union/management-union committee). } \\
\text { Average from latest CAs }\end{array}$ \\
\hline
\end{tabular}

Note: $\mathrm{CA}=$ collective agreement; $\mathrm{R}=$ ratio; $\mathrm{O}=$ ordinal. All variables are ranked according to an ordinal scale of $0-5$ or $0-2$ (the latter being necessary because of small variability in the sample size). In each measure, 0 represents a complete absence of provisions for the variable, 1 represents the weakest provisions, and a score of $5(0-5)$ or $2(0-2)$ represents the strongest provisions when measured against other collective agreement language in the sector. All ratio-level data is averaged from the previous four collective agreements, while ordinal-level data is averaged from the latest collective agreement of each bargaining unit. 
Table 1. In total, there are seven all-in faculty association cases, four separate bargaining unit faculty association cases, and eleven separate union cases.

Our qualitative analysis relies on semi-structured interviews with key informants in academic unions about how different bargaining structures and relationships influence internal debates about sessional contract academic faculty, bargaining priorities, and collective bargaining strategies. The interviews explored what factors drive, colour, or influence the relationship between bargaining unit structures and organizational dynamics over time. While we conducted interviews with three dozen past and present union officials, tenured faculty, and contract academic faculty members at six Ontario universities and umbrella labour organizations, in this article we focus our attention on data gathered through interviews with 23 key informants at CAUT, CUPE, and three universities that exemplify each of the three different bargaining structures for sessional contract academic faculty: Brock University, Western University, and Wilfrid Laurier University (WLU).

It is important to acknowledge that the effect of a particular bargaining unit structure on bargaining outcomes is difficult to measure because other factors, not all of which are easily quantifiable, may shape certain outcomes. These factors include the length of the bargaining relationship, the economic context in which a unit was certified, the size and/or relative financial health of a particular university, the labour relations environment or culture at a particular university, the level of localized militancy, and the qualities, abilities, and inclinations of the specific actors who negotiated the contracts. In addition to bargaining structures, all these factors help to shape bargaining outcomes to some degree. With this in mind, we chose three universities with differentiated structures that also had in common other factors known to influence bargaining outcomes.

At Brock University, sessional contract academic faculty and full-time faculty are in separate unions. At Western University, sessional contract academic faculty and full-time faculty are in the same union and same bargaining unit. Finally, at Wilfrid Laurier University, sessional contract academic faculty and full-time faculty are in the same union but separate bargaining units. Brock, Western, and wLU are good comparators because they are all publicly funded universities located in southern Ontario, all have similarly sized undergraduate student populations, and the unionization of contract academic faculty at each university occurred in the same period: between 1998 and 2001. Moreover, strikes by academic unions on these campuses are rare.

Western, located in London, was established in 1878 as the University of Western Ontario (Uwo). It grew substantially after World War II and is considered a research-based doctoral university. Professors at Uwo founded the University of Western Ontario Faculty Association (UwOFA) in 1955 but did not certify it as a labour union until 1998. The unionization effort involved organizing both full-time and contract faculty into the same bargaining unit. Faculty at Western's affiliated colleges are represented by separate associations. 
The faculty bargaining unit has never struck but regularly participates in strike votes, having authorized strikes in 2006, 2010, 2014, and 2018.

WLU, located in Waterloo, was originally established in 1911 as the Evangelical Lutheran Theological Seminary of Eastern Canada. In 1925, it began offering non-theological degree programs and by 1958 professors had established a faculty association. In 1960, the seminary was renamed Waterloo Lutheran University. In 1973, the university's name was changed again, to Wilfrid Laurier University. In 1988, the Wilfrid Laurier University Faculty Association (WLUFA) became a certified labour union that included both full-time professors and professional librarians in the same bargaining unit. In 2001, contract faculty joined WLUFA as a separate bargaining unit. WLU opened a second campus in Brantford in 2006 for which WLUFA also has bargaining rights. WLU has transformed itself into a comprehensive university, offering a mix of undergraduate and graduate programs. The full-time faculty bargaining unit has never struck but has participated in at least four strike authorization votes since 1990 . The contract academic faculty bargaining unit regularly participates in strike votes but has only struck once, in 2008.

Brock University, located in the Niagara Region, was founded in 1964 as a primarily undergraduate university. A faculty association was established in 1965 to represent the interests of professors but the association did not become a certified union until 1996, when full-time professors and professional librarians at Brock decided they needed formal union recognition to defend and advance their interests. ${ }^{24}$ Sessional faculty, who were left out of the Brock University Faculty Association (BUFA) certification effort, joined with teaching assistants, marker-graders, course coordinators, and part-time lab demonstrators to organize Unit 1 of Local 4207 of the Canadian Union of Public Employees in 1998. CUPE 4207 has gone on to organize two additional bargaining units: Unit 2, in 2007, for full-time coordinators in the university's English as a Second Language (ESL) program; and Unit 3, in 2011, for ESL instructors. Having greatly expanded in recent decades, Brock is now considered a comprehensive university. Brock has never experienced a strike of full-time or sessional faculty, and even strike votes are rare. BUFA has only ever taken one strike vote, in 2006, while Unit 1 of CU PE 4207 took strike votes in 2004, 2010, and 2017.

\section{Bargaining Structures}

Unionization is RELATIVELY new to university teachers in Canada, with the first units being certified in the mid-1970s. The bargaining structures for university teachers have evolved unevenly for reasons related to region, local 
culture, and autonomy, as well as the personalities and preferences of the actors involved in certification efforts. Because CAUT did not officially support unionization up until the mid-1970s, university teachers who certified in that period had no clear template to follow. In the years that followed, CAUT eventually became an advocate for union certification and began offering support services, but its direct role in organizing was minimal. It was not until the early 2000s that CAUT became actively and systematically engaged in certification efforts and began advocating for a particular bargaining structure: the all-in model. ${ }^{25}$ However, by this time, most faculty associations across Canada had already certified, producing a patchwork quilt of campus-specific bargaining structures with important regional variations. ${ }^{26}$

Part of what prompted CAUT to become more involved in certification drives was the sector's growing reliance on contract academic faculty - perceived as both a threat and an opportunity from a union perspective. On the one hand, greater reliance on sessional instructors was viewed as a threat to the job quality and continued existence of traditional tenured or tenure-stream positions represented by faculty associations. On the other hand, organizing per-course instructors was viewed as the key to rendering their labour more expensive and thus mitigating their growth within the sector. These arguments were used to convince non-union faculty associations to certify using an all-in model that would lessen the ability of a university administration to pit tenured faculty against contract academic faculty. ${ }^{27}$

Arguments for the all-in model also focus on the importance of solidarity in achieving better terms and conditions of work for both contract faculty and tenured faculty. ${ }^{28}$ One interviewee associated with CAUT offered the following arguments in support of all-in bargaining units:

I think that's where we can make the best gains for everybody. It gives you more strength at the bargaining table ... It helps to avoid the tendency from the administration to try and divide and conquer and to put one group against the other. You still have to, when you're bargaining for everybody at the same time, take into account different interests, but it can be much easier for the administration to divide the membership on the basis that parttimers didn't get anything because the full-timers took it all in their round of bargaining. So trying to put bargaining demands in one big package helps build solidarity, and it forces associations to take seriously the concerns of all the membership. ${ }^{29}$

25. CAUT official, confidential interview, 8 July 2019; former CAUT official, confidential interview, 10 October 2019.

26. For example, in Alberta, historically, university teachers were not covered by the provincial labour code. Instead, they were covered by a separate act that designated all academic staff, including contract academics, as members of a faculty association.

27. CAUt official, confidential interview, 8 July 2019; former CAUT official, confidential interview, 10 October 2019.

28. Eve S. Weinbaum \& Max Page, "Solidarity: An Argument for Faculty Unity," New Labor Forum 23, 1 (2014): 14-16.

29. CAUT official, confidential interview, 8 July 2019. 
At the same time, advocates of separate unions or bargaining units for sessional instructors argue that unity between contract and tenured faculty is "impossible," largely because both groups have distinct and competing interests. ${ }^{30}$ According to this line of thinking, separate structures enable contract academic faculty to more clearly articulate and achieve their own interests, rather than have them traded away or altogether ignored by the full-time faculty who typically control and dominate faculty unions. ${ }^{31} \mathrm{~A}$ central tension between full-time faculty and long-term sessionals is the desire of the former group to push for the creation of "good tenure-stream jobs" that may or may not be filled by their long-term sessional co-workers. One of the key roles of separate unions for sessional contract academic faculty is to protect particular long-standing members' access to long-term and stable work - a role that would be compromised in an all-in structure given the collegial decisionmaking processes of the traditional professoriate, which prioritize "merit" over seniority or length of service in hiring decisions. These tensions also play themselves out at the level of collective agreement.

\section{Quantitative Findings}

Of THE ELEVEN VARIABLes outlined in Table 3, separate unions received the highest average score in six. Separate unions were found, on average, to have better collective agreement provisions relating to wages, pension eligibility, benefits, institutional research supports, access to work, and cancellation. On average, separate bargaining unit faculty associations had superior provisions in the categories of contract notice, infrastructural access, collegial governance, and professional expenses. Finally, all-in faculty associations had, on average, the best collective agreement provisions relating to conversion.

Separate unions received a higher average score on the core monetary components (wages, benefits, pension eligibility) than all-in faculty associations and separate bargaining unit faculty associations. Separate unions received the highest wage score of 3.36 and hold an advantage over all-in faculty associations (2.94) and separate bargaining unit faculty associations (2.53) (see Table 4 for details on wages). On pension eligibility, separate unions received an average score of 2.45 , while all-in faculty associations scored 1.71 and separate bargaining unit faculty associations scored 1.25 . On benefits, separate unions again came out on top (2.55) ahead of all-in faculty associations (1.71) and separate bargaining unit faculty associations $(0.00)$. While separate unions did receive the highest average score for institutional research supports, the difference between the other two bargaining unit structures was negligible.

30. Ivan Greenberg, "Impossible Unity: Adjuncts and Tenure-Track Faculty," New Labor Forum 23, 1 (2014): 11-13.

31. Former CUPE official, confidential interview, 11 July 2019. 
Table 3: Variable Scores by Bargaining Unit Structure for Sessional Contract Academic Faculty

\begin{tabular}{|l|c|c|c|}
\hline Variable (Scale) & $\begin{array}{l}\text { All-in faculty } \\
\text { associations }\end{array}$ & $\begin{array}{l}\text { Separate } \\
\text { bargaining } \\
\text { unit faculty } \\
\text { associations }\end{array}$ & Separate unions \\
\hline Wages (0-5) & 2.94 & 2.53 & 3.36 \\
\hline Pension eligibility (0-5) & 1.71 & 1.25 & 2.45 \\
\hline Benefits (0-5) & 1.71 & 0.00 & 2.55 \\
\hline Research supports (0-5) & 0.71 & 0.75 & 0.80 \\
\hline Access to work (0-5) & 2.00 & 2.25 & 2.77 \\
\hline Cancellation (0-5) & 1.35 & 1.15 & 1.97 \\
\hline Notice (0-5) & 2.43 & 3.93 & 2.51 \\
\hline Conversion (0-5) & 2.57 & 1.33 & 0.55 \\
\hline Infrastructural access (0-2) & 1.57 & 1.67 & 1.33 \\
\hline Collegial governance (0-2) & 0.31 & 0.50 & 0.44 \\
\hline Professional expenses (0-2) & 1.13 & 1.75 & 1.50 \\
\hline
\end{tabular}

Table 4: Average Sessional Wages, 2009-18

\begin{tabular}{|l|c|c|}
\hline Bargaining structure & $\begin{array}{l}\text { Average half-course } \\
\text { equivalent wage }\end{array}$ & $\begin{array}{l}\mathbf{2 : 2} \text { teaching load } \\
\text { equivalent wage }\end{array}$ \\
\hline All-in & $\$ 6,928.23$ & $\$ 27,712.93$ \\
\hline Separate bargaining & $\$ 6,501.38$ & $\$ 26,005.52$ \\
\hline Separate union & $\$ 7,147.33$ & $\$ 28,589.32$ \\
\hline $\begin{array}{l}\text { Separate union (excluding } \\
\text { CUPE Local 3903 at York } \\
\text { University) }\end{array}$ & $\$ 7,033.44$ & $\$ 28,133.75$ \\
\hline
\end{tabular}

On seniority and incumbency provisions, separate unions again had the highest average score of 2.77 , followed by separate bargaining unit faculty associations (2.25), and all-in faculty associations (2.00). Conversion provisions tended in the opposite direction, with all-in faculty associations having the strongest average score (2.57), separate bargaining unit faculty associations falling in the middle (1.33), and separate unions having a significantly lower score (0.55).

The variables of contract notice and course cancellation payment also yielded mixed results, with separate unions having the strongest score for cancellation (1.97) and separate bargaining unit faculty associations having the highest score for contract notice (3.93). Finally, on measures of infrastructural access, collegial governance, and professional expenses, separate bargaining unit faculty associations had the highest average scores. 
As previously discussed, other intervening variables can influence the CAPI measures in significant ways. One of the primary factors is the size of the institution. The largest institutions by full-time faculty - the University of Toronto, York University, the University of Ottawa, and Western University - had an average score of 4.0 on wages and 4.5 on pension eligibility, compared with the respective averages of 2.9 and 1.5 for medium and small institutions. This pattern is repeated to a lesser extent on benefits, institutional research supports, access to work, collegial governance, and professional expense funds, as large institutions receive higher scores than medium institutions, and medium institutions receive higher scores than small institutions. This is an important relationship to note as most separate unions are concentrated in large or medium-sized institutions. The maturity of the bargaining relationship is also an important factor that is not easily disentangled from bargaining unit structure or institution size. For example, sessional contract faculty at York certified in 1975, while their counterparts at WLU were only certified in 2001.

Additionally, when analyzing collective agreements in the university sector it is important to consider the potential skewing effect of Unit 2 of CUPE 3903, which represents sessional contract academic faculty at York. The unit is widely acknowledged as having the "Cadillac agreement" in the sector. While removing CUPE 3903 from calculations does have an impact by decreasing the average scores for separate unions, the separate union bargaining structure is able to maintain the highest scores in terms of wages, pension eligibility, benefits, access to work, and cancellation even without CUPE 3903 in the mix.

\section{Qualitative Findings}

While QUANTITATIVE FINDINGs based on an analysis of collective agreement provisions provide us with a clearer picture of collective bargaining outcomes for sessional contract faculty at Ontario universities, the extent to which these bargaining outcomes are influenced by particular bargaining structures or other factors requires deeper qualitative examination. To that end, we interviewed past and present union activists and officials at Western, WLU, and Brock: three comparable universities, all with different bargaining structures for sessional instructors. Interviews focused on the perceived merits of different bargaining unit structures and the nature of the inter- and intra-union conflict over efforts to define and prioritize the interests of sessional contract academic faculty.

\section{Western University}

Sessional faculty at Western, like full-time faculty, are members of UwofA and share the same bargaining unit. ${ }^{32}$ Faculty members involved in the 
certification effort offered competing explanations for why the association opted to pursue an all-in bargaining structure. ${ }^{33}$ "It was a deliberate strategy on our part," according to an interviewee with knowledge of the drive. Not only were advisers from CAUT advocating for the all-in model, "based on the notion of unity with a common interest of contract faculty and regularized faculty," but UWOFA "realized that getting enough potential members to sign cards at the time focusing just on regularized faculty ... was uncertain. We were confident that with contract academic staff included into the proposed bargaining unit as well, they would help us get a critical mass of signatures on cards." ${ }^{44}$ According to this strategic calculation, contract faculty were seen as key to UWOFA's achieving union status by helping the association meet the required threshold of signed union cards to trigger a certification election. One interviewee who participated in the organizing drive explained that sessional instructors made three times less than a similarly qualified tenure-track faculty member and had no access to benefits, thus making unionization a very attractive proposition for many in that job category. ${ }^{35}$ Another interviewee with intimate knowledge of the drive explained that, while it was true that sessional faculty were more willing to sign cards than their full-time counterparts, the decision to include sessionals was rooted in principle as much as in pragmatism: "It was a no brainer ... We do the same thing and we're going to be one union. There was opposition from the regular meritocracy who thought the part-timers would end up running the show or something, but there was very little pushback." ${ }^{36}$ The same interviewee pointed to an acrimonious three-week strike at York University in 1997 - a year before UwOFA was certified - as an example of how a university administration could pit university workers against one another when they did not belong to the same union. In that labour dispute, the administration's push to do away with contract provisions for post-retirement teaching created tension over the distribution of work between retired members of the York University Faculty Association and the precariously employed contract faculty members represented by Unit 2 of CUPE Local 3903. Faculty at Western were determined to avoid such a

university does not release data on how many of its contract faculty fall below this threshold and the number is unknown to UwOFA.

33. Interestingly, CUPE approached UWOFA to offer assistance in its certification campaign, but the offer was declined. Former uwOFA member, confidential interview, 15 August 2019; former CUPE official, confidential interview, 11 July 2019.

34. UWOFA member, confidential interview, 18 June 2019.

35. uWOFA member, confidential interview, 15 August 2019.

36. Former uwofa member, confidential interview, 15 August 2019. According to this interviewee, uwo professional librarians were also invited to join the certification effort but showed little interest in unionizing. Librarians would later organize as a second bargaining unit of UWOFA, in 2004. 
dynamic and thought an all-in structure would mitigate against divide-andconquer strategies used by university administrators. ${ }^{37}$

Some U WOFA interviewees argued that a rising tide lifts all boats when both full-time and sessional contract academic faculty are in the same bargaining unit. Put another way, contract academics benefit from the enhanced status and thus bargaining power of their full-time counterparts by virtue of being in the same bargaining unit. Implicit in this reasoning is the idea that sessionals would fare much worse in bargaining or have much less bargaining power on their own. "Because you're part of a very important group on campus that has a lot of support behind it and money, you're more of a threat that way to the administration," explained a former contract academic faculty member, who went on to argue that "the primary benefit is that we have been able to involve regular faculty who are sympathetic to the working conditions of contract faculty and because we've been able to do that, the issues of contract academic faculty have always been important at the table." 38

Another interviewee associated with UwOFA made a broader, more traditional industrial union argument in favour of the all-in model, based on the power of numbers:

I think we bargain more effectively in common where the right to strike can be exercised by a much larger group with the potential of causing a total cessation of teaching activity at the university while we're on the picket line. There is the fact of having a single collective agreement and having an appointment structure in which all the pieces fit together, where there's progression from one level to the other that does not involve moving from one bargaining unit to another. First of all it takes away any potential political issues of raiding another union's membership and it allows people to move to a different contract status, a different employment status within the same bargaining unit. ${ }^{39}$

At Western, the faculty association has made a concerted effort over the last few rounds of bargaining to specifically include bargaining priorities aimed at improving terms and conditions of work for contract academic faculty. "Because of the increased awareness of the situation of precarious contract academic staff, we've been able to go a good distance in convincing regularized faculty of the need to stand in solidarity with our contract academic staff, that our common interests outweigh what perceived contradictions there might be in our interests," explained one interviewee in response to a question about how the association manages to balance interests within the bargaining unit given the perceived power imbalance between groups of members. ${ }^{40}$ Another interviewee argued that because of a top-down management mindset among university administrators at Western, most tenured UwOFA members have come to understand that "rights are really indivisible. Whatever they do to

37. Former uwofa member, confidential interview, 15 August 2019.

38. Former UWOFA member, confidential interview, 6 September 2019.

39. UWOFA member, confidential interview, 18 June 2019.

40. UWOFA member, confidential interview, 18 June 2019. 
our more vulnerable colleagues, they're going to end up doing to the rest of us ... It's a sort of enlightened self-interest. You support people who are worse off than you not just because you're a nice person, but because eventually the same employer will screw you as well. That seems to have sunk in, generally." ${ }^{41}$

Most interviewees at Western who favoured the all-in model stressed the importance of communication, solidarity, and balance in achieving fairness for both full-time and per-course instructors in the bargaining unit. "I think having us all together forces us to have conversations about what is good for the university as a whole and how can we best each play our part and be protected in whatever that part is to contribute to making this a good university. And that's, I think, the main reason to have everyone all together, even though it creates some challenges of balancing things," explained one interviewee. ${ }^{42}$ They went on to defend UwOFA's all-in model as follows:

I think from the perspective of the labour movement and union solidarity and how power works, that it's a total advantage to have everybody all in, because it allows you to have conversations about the health and well-being of the entire scene, the entire spectrum of teaching and learning and research at Western. Whereas if you have your contract faculty in a different bargaining unit or a different union, it's much easier for the employer to hive off, "well, these are the real academics and these are whoever they are, these teaching machines" or however they're categorized. And I think that [separation] also makes full-time faculty not ever need to identify with that group. It becomes convenient for the full-time faculty to say, "oh, yeah, it sucks to be one of those people, but nothing we can do about it, because they're over there." And I've heard full-time faculty at other universities say that when they hear that we're all in at Western, "oh, that would be awkward" and I'm "for who?" right? "Awkward for you?"43

Not all of our interviewees at Western agreed that contract academic faculty issues are given priority in bargaining. Full-time faculty members tend to dominate all-in faculty associations, both numerically and in terms of decision-making bodies within these unions. In UwOFA, for example, between 15 and 30 per cent of members are sessional instructors, and only a few of them have ever served as officers of the association. ${ }^{44}$ While sessional instructors are not guaranteed representation on UWOFA's executive board or negotiating team, there is usually one representative from this group on the latter body. ${ }^{45}$ Full-time faculty have always dominated both bodies. These power imbalances have sometimes led to tensions in bargaining or in the lead-up to negotiations when members are being consulted about their priorities.

41. UWOFA member, confidential interview, 15 August 2019.

42. UWOFA member, confidential interview, 14 August 2019.

43. UWOFA member, confidential interview, 14 August 2019.

44. UWOFA member, confidential interview, 18 June 2019; former UwoFA member, confidential interview, 6 September 2019.

45. Former UWOFA member, confidential interview, 6 September 2019. 
Some interviewees were keenly aware of these imbalances and their implications. "A full-time faculty unit could probably do very well for itself at a bargaining table and I think the union does have to work to keep the full-time faculty 'on side,' if you will, when we're articulating the needs and desires of the contract faculty," explained one interviewee. ${ }^{46}$ "It would be impossible to get full-time faculty to go on strike to get better working conditions, or anything, for contract faculty," argued another interviewee. "And as a result, I think the contract faculty don't have, on their own, the ability to really improve their working conditions. They can't do anything about it. They can only rely on the regularized faculty to take on their cause and make it better." ${ }^{37}$

According to interviewees, chief among the concerns of contract academics are the issues of job security and access to work. Many support conversion of long-serving sessionals to traditional tenure-stream or permanent teaching-intensive appointments. However, neither of these objectives has been achieved, let alone prioritized, in UWOFA's collective bargaining for reasons previously alluded to, related to the desire of full-time faculty to preserve their collegial decision-making power over full-time faculty appointments. Despite the resistance to conversion language, UWOFA has bargained a provision for standing appointments for long-term sessional instructors, which provides for "an ongoing non-probationary Part-Time Appointment to teach a defined teaching load, which can only be terminated by retirement, resignation, dismissal for cause or termination." ${ }^{48}$ Standing appointments, however, are not guaranteed in any way, must be supported by departmental committees and the dean, and can be terminated for a number of reasons, including "operational reasons" or because "the work of the Appointment is to be included in the Normal Workload of existing or new Full-Time positions." ${ }^{49}$

Although one interviewee acknowledged that among sessional faculty there are "voices occasionally expressed saying 'we need to decertify from UwOFA, they don't defend our needs. We need to go on our own," the general sentiment expressed by interviewees was that sessional instructors would be even worse off in their own separate union..$^{50}$ One interviewee argued that those few members who supported a new bargaining structure "were colleagues whose assessment was simply incomplete and uninformed." ${ }^{11}$ The same interviewee went on to argue that faculty associations are better equipped to bargain on

46. UWOFA member, confidential interview, 14 August 2019.

47. Former Uwofa member, confidential interview, 6 September 2019.

48. Faculty Collective Agreement between The University of Western Ontario and The University of Western Ontario Faculty Association, 1 July 2014-30 June 2018, Article 1.4.1, 31.

49. Faculty Collective Agreement between The University of Western Ontario and The University of Western Ontario Faculty Association, Article 18.10, 51.

50. UWOFA member, confidential interview, 18 June 2019.

51. UWOFA member, confidential interview, 18 June 2019. 
behalf of sessional contract faculty because their focus is exclusively on academic labour and, unlike CUPE, they are not bound by bargaining mandates imposed from on high. ${ }^{52}$

A former contract academic faculty member summarized their mixed feelings about UWOFA's all-in bargaining structure as follows:

Given all the limitations, I think UWOFA has done a pretty good job. We know UWOFA is not going to go out on strike for contract faculty issues, but we keep hammering away on them. So I would say UWOFA has done a pretty good job, but it's not like there has been any major successes. All the problems are still there. The standing appointments for part-timers that UWOFA bargained years ago, the university just quickly figured out a way to avoid giving people those, so people who got them at the time were successful, but after that there has not been growth in the number of people with standing appointments. I don't see many successes at other places either, though, so maybe uwofa has done better. ${ }^{53}$

One of the interesting dynamics at Western is that criticism of UwOFA's handling of contract academic faculty issues comes both from sessional instructors, some of whom think the union does not do enough to promote and follow through on their specific issues, and from certain tenured professors, who think the union does too much to foreground and push for issues they consider relevant to only a small minority of members. ${ }^{54}$ One UwOFA member familiar with the union's collective bargaining agenda explained how the union balances interests in this climate:

We are foregrounding our work on behalf of our contract academic staff members because of their greater need for job security, for fair compensation. Because of their precarious situation, they are in need of that amount of attention. But we also say, at the same time, while we might appear to be foregrounding the interests of the minority of our members, we are advocating for the fundamental rights of all faculty to appropriate compensation, academic freedom, appropriate evaluation procedures and all of these matters that affect all of us ... We appeal to the higher value of the academic mission of the university as our united faculty association ... we uphold the academic mission. ${ }^{55}$

Such appeals, however, seemed to resonate far more with full-time than with contract faculty interviewees. Unconvinced that UwOFA's bargaining structure could deliver the goods for sessional instructors, one contract academic faculty member argued instead for a province-wide union and bargaining unit for all contract faculty: "I think that would solve a lot of problems. But it can't be CUPE or [the Ontario Public Service Employees Union]. It has to be a faculty-focused, university-focused union that just works for contract

52. Although in principle CUPE is a national union with bargaining mandates, in practice the union has a very decentralized structure with significant autonomy for locals in crafting their bargaining agendas.

53. Former uwofa member, confidential interview, 6 September 2019.

54. UWOFA member, confidential interview, 18 June 2019; uwoFA member, confidential interview, 14 August 2019.

55. UWOFA member, confidential interview, 18 June 2019. 
faculty ... Despite the potential issues of having to bargain centrally, we could shut down the entire university system ... and then people would realize just how important we are to keeping these institutions running." ${ }^{.56}$

\section{Wilfrid Laurier University}

Sessional instructors at WLU are represented by WLUFA but were organized in 2001 as a second bargaining unit alongside the existing full-time faculty unit that certified in 1988. According to one interviewee familiar with the 1988 certification campaign, when professors unionized they did not opt for an all-in model that included part-timers because "there were so few part-time people that it really wasn't an issue and most of them weren't career academics ... it was not their main source of income ... and those who were there weren't interested." ${ }^{57}$ How the union came to adopt the two bargaining unit structure when part-timers eventually joined in 2001 is a matter of some debate. One WLUFA interviewee claimed it was a strategic decision, "basically a product of a compromise," in that "it was the only way to get full-time faculty on board with the organizing campaign." ${ }^{58}$ Another figure closely associated with the organizing campaign disputed this claim, however, pointing out that Ontario's Labour Relations Act did not include a straightforward process to add new categories of organized workers to an existing bargaining unit. Therefore, the faculty association's decision to create a separate bargaining unit for part-time sessional faculty was driven more by the legal process than by any strategic considerations. ${ }^{59}$

The twelve-member WLUFA executive consists of both tenure-stream and sessional faculty with a constitutional requirement that at least four members come from each unit. The entire membership votes for every position on the executive, so full-time faculty influence which part-time faculty are elected to the executive and vice versa. The association's executive, however, has consistently been dominated by full-time faculty. ${ }^{60}$ There are no designated positions on WLUFA's full-time or part-time bargaining committees. Instead, the executive appoints the chief negotiator and then appoints a negotiating team in consultation with the chief negotiator. In the past, a full-time faculty member has been appointed to lead negotiations for the part-time unit. ${ }^{61}$ Moreover, the unified executive votes to recommend ratification of both full-time and

56. Former UwOFA member, confidential interview, 6 September 2019.

57. Former Wlufa member, confidential interview, 15 August 2019.

58. W LUFA member, confidential interview, 30 May 2019.

59. Former CAUT official, personal email communication, 30 November 2019.

60. WLUFA member, confidential interview, 30 May 2019; former w LUFA member, confidential interview, 14 June 2019.

61. Former WLUfA member, confidential interview, 13 September 2019. 
part-time faculty collective agreements before members of each respective unit vote on ratification for their contract only. ${ }^{62}$

Support for unionizing with WLUFA rather than with a separate union like CUPE was very strong among part-time instructors. "We wanted to be seen as faculty members at the university, not as public employees outside of the university," recalled one interviewee. They went on to explain that part-time faculty "were given assurances, I suppose, that we would be much stronger because even though we wouldn't be in the same bargaining unit, we would be connected to the full-time bargaining unit, that that gave wLUFA so much more power when it came to negotiating. So we had every reason to believe that that was the smart thing to do."63

However, wLUFA interviewees had mixed opinions about the benefits of the union's bargaining structure for sessional instructors. One interviewee described the primary benefit as follows:

I think it has to do with resources. So we have an office on campus. We have administrators on campus. We have an executive director on campus ... Being associated with CAUT, most of our members would make more on strike than they would teaching, because of the strike fund. Knowing what's happening from a regularized faculty position does help situate where negotiations go from a contract faculty point of view. We have the benefit of the expertise around the executive table. We can reach out to folks through wLUFA to get number crunching done. ${ }^{64}$

Another interviewee explained that "one of the important things that having two units in the same union has achieved is that we're constantly talking to each other and sometimes that involves full-timers being not berated, but being told in no uncertain terms that they are not seeing the issues that contract faculty are facing." ${ }^{65}$ Sometimes, said another interviewee, at executive meetings you need to "remind everybody that we're representing all members. And what I've found is that ... full-timers often care about the contract faculty situation. And I do feel that a lot of full-timers seem to vote in favour of contract faculty initiatives ... I feel that we've been well respected by the full-time people on the executive."66

However, this sentiment was not universal. In 2016, a small number of sessional instructor members of the association formed the "Caucus for a Democratic Union" and began to explore breaking away from WLUFA and joining CUPE. Inspired by the benchmark bargaining breakthroughs of CUPE Local 3903 at York University, and annoyed by the perceived indifference of full-time faculty who effectively "controlled" the association, the group began

62. Former w LUFA member, confidential interview, 14 June 2019.

63. WLUFA member, confidential interview, 30 May 2019.

64. WLUFA member, confidential interview, 27 May 2019

65. WLUFA member, confidential interview, 18 July 2019.

66. WLUFA member, confidential interview, 11 July 2019. 
openly agitating for change and even took part in and helped organize information sessions hosted by CUPE on campus. ${ }^{67}$ As one interviewee recalled, proponents of leaving WLUFA to join CUPE argued that "we would be better represented. That we would be captaining our own ship, that we would be more responsive to our membership." ${ }^{68}$ A second interviewee argued that leaving WLUFA and joining CUPE would allow "greater independence of thinking and movement. If you're at all connected then there's an obligation to one another, and currently we have never been served by tenured faculty. They often say the right thing, but take no action." ${ }^{\prime 9}$ A formal displacement drive never got off the ground, however, as support for leaving W LUFA fizzled. Two interviewees indicated that WLUFA strategically decided to join NUCAUT, an affiliate of the Canadian Labour Congress, in order to block CUPE's effort to raid WLUFA's part-time faculty members. ${ }^{70}$

One interviewee who expressed support for the breakaway effort explained that part-time faculty "do work hard on these executives, but they also get linked to a kind of language and a kind of practice that doesn't press the limits ... And [faculty associations] are not willing to include the voices of people who would press those points." ${ }^{71}$ Here, the interviewee was advocating for a particular kind of faculty unionism; they made it clear that part of the desire to have a separate union was also ideological, describing WLUfA as "conservative" or a "business model," in contrast to CUPE, which the interviewee considered to be more "activist" in its approach. ${ }^{22}$ "I think the feeling was that the contract faculty were not being included in the functioning of the union in a way that was as meaningful as it needed to be. That they often felt that they were forgotten or if they were remembered that it was sort of a lip service that was being paid to them," explained another interviewee. ${ }^{73}$

Interviewees were divided on the question of whether joining CUPE would benefit sessional faculty. One interviewee explained, "CUPE, when it goes to job action, is very effective because it's so large and that's where being a part of

67. WLUFA member, confidential interview, 27 May 2019; former w LUFA member, confidential interview, 14 June 2019.

68. WLUFA member, confidential interview, 27 May 2019.

69. WLufa member, confidential interview, 19 June 2019.

70. Raiding is an attempt by one union to induce members of another to defect and become members of the raiding union. A key role of the Canadian Labour Congress is to regulate relations between member organizations, including enforcing rules and procedures for workers leaving one union to become members of another. By joining the Canadian Labour Congress via NUCAUT, a faculty association falls under the protection of the CLC's anti-raiding rules, making it much more difficult for another CLC affiliate to take over the membership of the faculty association.

71. WLUFA member, confidential interview, 19 June 2019.

72. WLufa member, confidential interview, 19 June 2019.

73. WLUFA member, confidential interview, 18 July 2019. 
a faculty association group is sometimes a disadvantage. We're quite isolated as far as our reach goes. If you're part of CUPE and you go into job action, then all of a sudden you're tens of thousands of people strong across the province."74 However, the same interviewee also expressed opposition to sessional faculty joining CUPE, arguing that many of that union's collective agreements are negotiated by staff representatives who do not come from the university sector or may never have attended university themselves. They elaborated on this point as follows:

I am not always convinced that CUPE negotiates as though it represents faculty in particular. I think CUPE has a public employees approach to bargaining ... I think that faculty associations in particular are well positioned to negotiate terms that reflect the culture and character of their own universities, whereas CUPE has a model that seems to be laid over everything, that doesn't necessarily respond in a sympathetic way within the space that it's negotiating ... Faculty Associations have more of a tendency to do a true negotiating with the employer, which is a bit more of a back and forth, because we live with that employer. ${ }^{75}$

While a number of interviewees were sympathetic to the idea of a standalone union for part-time faculty, an even greater number expressed support for an all-in bargaining model, one that would combine full- and part-time faculty in the same bargaining unit, as the best way to win better terms and conditions of work for sessional instructors. "I do think in a way that we would have a better situation if we were bargaining together at the same time, because this year we're in negotiations and we're always thinking if we could bargain at the same time, then the full-timers and the admin would have to consider our situation a little differently than they do now. It seems that we're always in a one-down position by having to bargaining separately," explained one interviewee. ${ }^{76}$ This opinion was rooted in the belief that the all-in model was best able to rectify the power imbalance between part-time and full-time faculty, an imbalance exacerbated by having two separate bargaining units and no rights embedded in either collective agreement explicitly protecting members' right to not cross the picket lines of the other bargaining unit.

One of the major concerns expressed by interviewees was over the university administration's ability, under the current model, to pit bargaining units against each other. "The full-time faculty have more pull. If something goes wrong with those negotiations, [WLU administration] is in big trouble. So they get more respect definitely," said one interviewee, who went on to argue that potential job security gains for part-time faculty were dependent on the consent of full-time faculty given the union's structure and the way

74. WLUFA member, confidential interview, 30 May 2019.

75. WLUFA member, confidential interview, 30 May 2019.

76. WLUFA member, confidential interview, 11 July 2019. 
the two collective agreements interacted. ${ }^{77}$ Another interviewee explained the implications of this dynamic as follows:

The university can pit us against each other and so while we try and make gains, the university can come back and say "no, no, that is only negotiated in the full-time agreement." And then the full-timers might say "it has nothing to do with us, that needs to be negotiated in the contract faculty agreement." I know that contract faculty issues have made it, at least early on, on the full-time bargaining table, but they get dropped off. You've got to get your membership to approve what you're moving forward with and there are some full-time faculty members who are very supportive of contract faculty issues, but I think with the current state of post-secondary education that many faculty members are just burying their heads ... so, I think that our issues get dropped off the table. ${ }^{78}$

For example, a number of interviewees raised the issue of conversion language that has been a long-standing priority for sessionals seeking greater job security. According to various interviewees, many wLUFA sessional faculty members want conversion language similar to that in place at York University, where CUPE Local 3903 has negotiated language to transition a certain number of long-serving members from the contract academic faculty bargaining unit into the faculty association as tenure-track positions. ${ }^{79}$ Resistance to conversion, however, comes from both WLU senior administration and the tenured faculty bargaining unit - condemning the proposal to almost certain defeat. As one interviewee stated, "Contract faculty always want more job security and I think that's universal no matter which university we're talking about." They went on to say that "sometimes I think that the full-time faculty are sympathetic with the administration. They don't want contract faculty to have that job security, because they want the best person in the classroom, which is understandable. I get it. But they don't recognize that the person that they've had in the classroom for the last five years is the best person." ${ }^{80}$ Because appointment provisions for full-time faculty are covered by the fulltime agreement, conversion language for part-time members must, in some way, interact and cooperate with the language in the part-time agreement on this subject. Full-time faculty, however, have shown little interest in advancing strong conversion language for the benefit of part-time members. One interviewee explained that "contract faculty often feel that their full-time colleagues don't appreciate the work that they do and are always looking out for someone better." ${ }^{\prime 1}$ Another interviewee stated, "I think that they [full-time faculty] think that their rights are more important. Some of them do. Not all, but some of them feel that they're the real academics and that contract faculty,

77. Former WLUfA member, confidential interview, 14 June 2019.

78. WLUFA member, confidential interview, 27 May 2019.

79. Former WLUfA member, confidential interview, 14 June 2019.

80. Former WLUFA member, confidential interview, 14 June 2019.

81. WLUFA member, confidential interview, 27 May 2019. 
'you're just here to serve a small purpose and you kind of deserve your precarious situation." 82

Reflecting on WLUFA's bargaining structure for part-time faculty, one interviewee commented,

To have a single association represent two distinct bargaining units whose interests are going to unavoidably, at certain points, conflict with each other is a problem. If you have a bargaining unit, the contract faculty bargaining unit whose main goal has always been from the beginning of our organization to make our employment more secure in some way and then you have a bargaining unit whose main point is "protect what we already have and get us some more full-time faculty." They don't want to hear about ways in which they can help to create transitions between the bargaining units. They don't want that at all. ${ }^{83}$

The association has proposed more modest job security proposals, like continuous renewable appointments with a set number of courses and a salary rather than an hourly wage, without too much objection from the full-time unit, but these job security measures have so far not been achieved in bargaining. ${ }^{84}$ While the full-time collective agreement does include a provision that guarantees a part-time faculty member with seniority an interview for a fulltime teaching-intensive position that is expected to cover courses currently taught by the part-time member, not a single informant we spoke to could think of an instance where a sessional faculty member had been successful in moving across collective agreements. Interviewees expressed some fatalism about the possibility of breakthroughs on the conversion issue in the context of the current bargaining structure. "There's not going to be change that comes through the full-time agreement. What we've come to accept is that all we can do is attempt to bargain for the best continuing type of appointments that we can house within the contract faculty collective agreement," one interviewee explained. "The best that we've managed to get to this point is something that we call a standing appointment, which is an appointment for five years that guarantees the member a minimum number of courses and the minimum that can be granted is three." ${ }^{85}$ To be granted a standing appointment, part-time faculty must first meet a set of criteria to qualify, including approval by the dean and the part-time appointments committee at the department level. In other words, standing appointments are far from guaranteed. ${ }^{86}$

Several interviewees described the inability to achieve meaningful conversion language or guaranteed standing appointments as the product of the limitations of having a separate bargaining unit for sessional instructors. One interviewee commented, "There is no question that if we had been a single

82. WLUFA member, confidential interview, 11 July 2019.

83. wlufa member, confidential interview, 30 May 2019.

84. Former wlufa member, confidential interview, 14 June 2019.

85. WLUFA member, confidential interview, 30 May 2019.

86. WLUFA member, confidential interview, 27 May 2019. 
[all-in] unit ... that would have benefited our contract faculty members. If nothing else happened, it would mean that having some kind of possibility for conversion would probably have been written into our collective agreement and it probably would have been done ages ago." ${ }^{87}$ Put another way, the perceived advantage of an all-in structure is that it is more likely to produce solutions that benefit both part-time and full-time faculty in a meaningful way. Another part-timer provided wider context for supporting the all-in model:

The administration knows that the only kind of currency we have at the bargaining table is the ability to withdraw our work, withdraw our service. That's pretty much it. But when you're sitting at the full-time bargaining table, they're dealing with a group of people who have tenure. They're not going to go anywhere. They're not going to disappear. They're not going to leave. The university simply has to strike a deal with them, because there's no other place to go. So to some extent, anyway, it's a bit of a role reversal at the full-time bargaining table where the administration has a group that they have no choice but to come to an agreement with because they've got tenure. You go to the contract faculty bargaining table and it's a whole other ball game. For the most part they see us as expendable, they see us as temporary, they see us as not having that great an impact on the university with the exception of when we withdraw our work. So, yeah, and even the withdrawal of work has worked out for them in the past, because of the way that sometimes they have stretched negotiations on so that we end up at the point of ... for instance, when we did go on strike, I think it was already after reading week in February and so there were so few weeks left of the term, and all of our contracts end as of April 30th, and so we're technically not employed by the university anymore after April 30th, so you can't be walking a picket line to withdraw services when you're not an employee any more. The administration knows what kind of a wall we're up against. ${ }^{88}$

Given the growing proportion of teaching positions filled by part-time faculty at WLU and across the university system, academic unions and associations are having to confront this new reality. However, strategies of resistance, on the one hand, or accommodation, on the other, have been uneven and coloured by local bargaining structures. One interviewee explained, "I think [at] a lot of universities, tenure-track faculty just have their heads in the ground still. I think at Laurier there is an understanding because we are in such open dialogue all the time that change is going to be necessary. Our task is, how do we best guide that change to benefit both units?" ${ }^{89}$

\section{Brock University}

On campuses where full-time and sessional contract academic faculty are represented by separate unions, many of the intra-union struggles and tensions that all-in faculty associations contend with are avoided. Instead, there are inter-union tensions over the perception that collective bargaining gains accrued by full-time professors come at the expense of sessionals in a different

87. WLufa member, confidential interview, 30 May 2019.

88. WLUFA member, confidential interview, 30 May 2019.

89. WLUFA member, confidential interview, 18 July 2019. 
union. As one interviewee put it, "faculty, they take what they want and leave the scraps for everybody else. That's at least the sentiment that's out there."90

This kind of tension has been in evidence at Brock, where the faculty association sometimes finds itself at odds with CUPE Local 4207, which represents sessional instructors. When the Brock University Faculty Association unionized in 1996, its executive board made a conscious decision to exclude sessionals from the proposed bargaining unit, which included full-time faculty and professional librarians. Before the faculty association was formally certified, a long-time sessional wrote to the BUFA executive, asking it to consider expanding the scope of its unionization effort to include all academic workers on campus, including part-time instructors and teaching assistants. That request was denied. "It's not the same. It's not the same kind of responsibilities, not even the same kind of privilege and it's not the same kind of role that we would perhaps think of more traditionally in terms of faculty associations," explained one interviewee with intimate knowledge of the certification effort. "When that stuff came up, I mean, we were not even prepared for it ... At the time, contract faculty weren't even on the radar ... It's not that there were none, but there were nominally none. They weren't evident. They weren't visible." 91

Turned away by the faculty association, sessional instructors organized two years later with teaching assistants, part-time lab demonstrators, and marker-graders into CUPE Local 4207. Since Local 4207's certification in 1998, the number of courses that can be taught by sessional instructors in a given academic year, both individually and collectively, has been a source of interunion tension. Outside of Brock's Faculty of Education, the BUfA collective agreement caps the share of credit courses that can be taught by non-BUFA members at 14 per cent. Moreover, the certification order in the BUFA collective agreement prevents individual sessional instructors from teaching more than four half courses in one year. ${ }^{92}$ CUPE 4207 has consistently, yet unsuccessfully, challenged this latter provision as an impediment to its members' ability to teach more courses and therefore make greater earnings. ${ }^{93}$ BUFA's leadership has steadfastly refused to negotiate on the number of courses that can be taught by CUPE members, fearful that it would open the door to allowing a greater proportion of courses at the university to be taught by non-BUFA members, who, in the eyes of several faculty association interviewees, are generally viewed as less qualified and less experienced. "There was some heated discussion back and forth certainly about those things ... That definitely put

90. Former CUPE Local 4207 member, confidential interview, 2 July 2019.

91. BUFA member, confidential interview, 24 June 2019.

92. Collective Agreement between Brock University and the Brock University Faculty Association, 1 July 2017-30 June 2020, Appendix A, 165.

93. CUPE Local 4207 member, confidential interview, 29 May 2019. 
us at odds with CUPE's needs and that was a real ambivalence," explained one interviewee familiar with the ongoing disagreement. ${ }^{94}$ Another interviewee associated with BUFA was more blunt, explaining, "When [sessionals are] in a separate union, it's easier for BUFA to just say 'no' and to be very protectionist." 95

Despite the material gap in pay and benefit entitlements between sessionals and full-time faculty, interviewees associated with CUPE were divided on the question of whether sessional instructors at Brock would be better off in the faculty association. Some argued that, given BUFA's relatively stronger bargaining power, membership in the faculty association would undoubtedly increase prospects for better terms and conditions of work for sessional instructors. ${ }^{96}$ However, other interviewees thought the separate union structure enabled sessionals to more clearly articulate and achieve their interests, especially those that are sometimes at odds with full-time faculty. ${ }^{97}$

For example, disputes over hiring and the right of departments to control who teaches its courses can be very contentious. The most senior qualified model embedded in the CUPE collective agreement does not always sit well with BUFA members, who are not used to considering seniority in tenurestream job competitions. An interviewee associated with BUFA explained, "Hiring decisions very much colour the relationship between both groups because faculty are responsible for recommending part-time teaching appointments." ${ }^{98}$ Another faculty association interviewee, who expressed annoyance with CUPE's approach to grievance handling on this issue, stated, "When it comes to [CUPE instructors], faculty should be able to make our own decisions. We're the best to make those decisions. 'This is what I do, this is what I am, you may come and go, I'm here."'99

"It does strike me that bargaining outcomes can't really be divorced from a pattern of grievance handling," explained one interviewee associated with CUPE. They went on to explain,

Most of the action that we got for sessionals was through the grievance procedure, where a department had denied them work, usually on grounds of not meeting the qualifications. And that, I think, is something that, having an independent voice, strengthens their position. Faculty tends to defer to the power of the chair over the hiring decisions of non-faculty members and, quite frankly, faculty like to cherry-pick who they have in the department, so having a voice outside of the faculty association advocating through hiring grievances

94. Former BUFA member, confidential interview, 17 July 2019.

95. BUFA member, confidential interview, 19 June 2019.

96. CUPE Local 4207 member, confidential interview, 29 May 2019.

97. Former CUPE Local 4207 member, confidential interview, 2 July 2019.

98. BUFA member, confidential interview, 19 June 2019.

99. BUFA member, confidential interview, 24 June 2019. 
strengthens the position of sessionals. At least it prevents the faculty association from squashing their grievances in order to reaffirm the privilege of the tenured faculty. ${ }^{100}$

Proponents of separate unions for sessionals also argued that this model is better at delivering job security and access to work. According to one interviewee, "The threshold model of hiring is not one that faculty unions ever want to negotiate, even for themselves." 101 They explained further, "Credentialism is at the core of the myth of the meritocracy. I saw time and time again how faculty wanted to get rid of excellent instructors because they wanted somebody new. They wanted somebody with a more recent degree or they wanted somebody who had completed a degree with the assumption that a completed degree somehow made somebody a better teacher."102

For their part, interviewees associated with the faculty association were united in their belief that CUPE sessional instructors would likely be able to secure better terms and conditions of work as members of BUFA. "I think [sessionals] would be part of a stronger union in the faculty association, on this campus anyway. I think that [BUFA] would work hard to move them into more equivalent status in terms of things like resources and security and maybe even from within the union they could argue more for that path to more permanent work," reasoned one interviewee. ${ }^{103}$ It is worth noting that there are currently no provisions in either collective agreement for sessional instructors to convert to tenure-stream positions, and no special rights or privileges are afforded to sessionals applying for BUFA bargaining unit positions. Another interviewee explained why an all-in model would likely deliver better outcomes for sessionals:

We're all performing similar tasks in different kinds of ways, and if we are going to be able to advocate for part-time folks and we're going to be able to advocate for full-time folks and librarians, the whole crew, it's better if we're all together, because then folks can give us a sense of what the issues are. There will always be issues that divide us, but it would be far better if we could struggle with those issues together rather than stand the possibility of being pitted against one another. If we're all part of the same union, we're going to have schisms, we're going to have fractures, we're going to have arguments like we do with the Business School, for example. But it's better that those are done in-house, in my opinion, because then when you come forward collectively, you come forward collectively. And no one is going to get exactly what they want, but I think we can do better for everyone if we're doing it collectively not being pitted against one another. ${ }^{104}$

In general, faculty association interviewees reasoned that BUFA's relative bargaining power vis-à-vis the university administration better positioned

100. Former CUPE Local 4207 member, confidential interview, 2 July 2019.

101. In the threshold model of hiring, a job is awarded to the most of senior of qualified applicants as opposed to the most qualified applicant.

102. Former CUPE Local 4207 member, confidential interview, 2 July 2019.

103. BUFA member, confidential interview, 29 May 2019.

104. Former BUFA member, confidential interview, 17 July 2019. 
it to bargain improvements for all its members. Some interviewees pointed specifically to the small contingent of professional librarians with the association - who, on average, they argued, enjoy comparatively better terms and conditions of work than their counterparts at other universities - as evidence that BUFA's bargaining power is strong enough to lift all segments of its membership. ${ }^{105}$ That said, some interviewees were also quick to point out that they were not interested in having sessionals switch unions and join the association. ${ }^{106}$ This was not presented as a principled or solidaristic opposition to raiding, but rather as a preference for the two groups to remain in separate unions. One BUFA interviewee expressed concern that the inclusion of sessionals in their bargaining unit would escalate intra-union tensions and dilute the focus of the faculty association. ${ }^{107}$

Another interviewee explained their opposition to an all-in bargaining structure as a rejection of a more radical streak in the politics of CUPE's sessional union activists: "I do not think the majority of BUFA members would ever want to bring in sessional members alongside. Unfortunately, part of that resistance might have nothing to do with the jobs these people do, but [is] about the culture of CUPE that has developed on campus. People wouldn't be able to look past that entrenched militant culture to see 'these are also education workers and we should be trying to make the best working conditions possible." 108 The same interviewee went on to express the view that "many BUFA members see themselves first and foremost as professionals, as professors who happen to teach at a university where the faculty is unionized. Many CUPE activists, on the other hand, see themselves first and foremost as trade unionists."

These inter-union tensions, expressed both as political differences and as differences in bargaining aims and interests, have to some extent hindered the ability of both organizations to work together in pursuit of common interests. "I think it has varied over the years. Sometimes it's been cordial, sometimes it's been stressful, and sometimes we collaborated, meaning it's more than cordial, it's actually a joint effort to accomplish something or other. Part of it is dependent on the conditions of the specific case that might have emerged at a particular point in time and also the personalities of the Presidents," explained one interviewee associated with the faculty association. ${ }^{109}$ They and other interviewees went on to note that there are moments when both unions are cooperative, usually in response to an action from senior administration

105. BUFA member, confidential interview, 19 June 2019.

106. BUFA member, confidential interview, 29 May 2019; BUFA member, confidential interview, 19 June 2019; BUfA member, confidential interview, 24 June 2019.

107. BUFA member, confidential interview, 29 May 2019.

108. BUFA member, confidential interview, 19 June 2019.

109. BUFA member, confidential interview, 29 May 2019. 
that impacts the entire university community, like across-the-board cuts or a directive from Human Resources that negatively impacts all university employees. Cooperation, however, has been almost exclusively defensive. The unions do not proactively coordinate on bargaining issues or grievance handling. ${ }^{110}$

"We have different goals ... Promote your folks like you should. Take leadership like you should, yet don't ask us for anything," explained one interviewee associated with the faculty association. ${ }^{111}$ A different interviewee associated with BUFA offered a more nuanced view: "Historically, BUFA has taken the position that it can't necessarily sign on to support the specifics of CUPE's bargaining asks because, in some cases, they counter our own agenda, but BUFA will always issue public statements of support for their right to bargain, hope that they get a good settlement, etc."112 For example, according to this interviewee, most BUFA members would likely side with senior administration and reject CUPE's traditional bargaining position that no priority in hiring be given to graduate students when hiring for instructor positions - a key bargaining issue for long-serving sessionals who are not students.

Another interviewee associated with the faculty association stated, "I would say BUFA is far more complicit in trying to work with the administration, trying to advance administration proposals while still trying to look out for their members." ${ }^{113}$ This interviewee went on to frame the dynamic as follows:

CUPE had a pretty anti-administration positioning. They had been screwed over pretty well for an extended period of time and the neoliberal initiatives hit them earlier than it hit the faculty. So they were already at odds with the administration and were taking pretty radical stances. Now you could argue whether those were wise stances or good strategies; personally I don't think many of them were, but the positioning of the two were really at odds with one another. CUPE was far more radical in its stance towards the administration, [and] BUFA was far more conciliatory. ${ }^{114}$

This sentiment was not controversial. Virtually all interviewees, regardless of union affiliation, agreed that the university's human resources staff and senior administration treat BUFA with greater respect. "Because I think they listen to us [BUFA] more. I think they see us as more like them and probably we can relate more to how they think and what they think," 115 observed one interviewee associated with BUFA. Part of the explanation for this is that the

110. BUFA member, confidential interview, 19 June 2019; BUFA member, confidential interview, 24 June 2019; CUPE Local 4207 member, confidential interview, 29 May 2019; former CUPE Local 4207 member, confidential interview, 2 July 2019.

111. BUFA member, confidential interview, 24 June 2019.

112. BUFA member, confidential interview, 19 June 2019.

113. Former BUfA member, confidential interview, 17 July 2019.

114. Former BUFA member, confidential interview, 17 July 2019.

115. BUFA member, confidential interview, 29 May 2019. 
faculty association is viewed, and views itself, as occupying the top tier of the hierarchy of academic labour on campus. "I think we [BUFA] are stronger in terms of organization and just in terms of money and resources," explained one interviewee. ${ }^{116}$ "I think [sessionals'] ability to negotiate is undermined by the transient nature of their membership," added another. ${ }^{117}$ "We see ourselves as the university," explained yet another interviewee associated with the faculty association, whereas "CUPE is just not the same. It's kind of like they're our students." 118 While this observation may come across as patronizing, it is worth keeping in mind that the campus context plays a significant role in shaping the views of full-time faculty members on this subject. For example, some interviewees associated with BUFA seemingly had a hard time disassociating sessional instructors from their broader local union, which as part of the same bargaining unit also represents teaching assistants, marker-graders, and part-time lab demonstrators, many of whom are indeed students. It was clear from interview responses that the association of sessional instructors with graduate and undergraduate student teaching assistants had a negative impact on the perceived status or prestige of sessional work in the eyes of fulltime faculty, thus reinforcing the idea that sessional contract academic faculty and full-time faculty have little in common.

\section{Conclusion}

WHILE THE EVIDENCE suggests that bargaining unit structures have some minor effects on collective bargaining outcomes, these outcomes are deeply intertwined and not easily isolated from other factors related to the relative size of universities, the maturity of the bargaining relationship, the level of localized militancy, the culture and priorities of faculty associations as particular kinds of unions, and the personalities and politics of those who control them at any given moment. Our analysis of the data reveals that, on average, sessionals in separate unions had better contract provisions relating to wages, pension eligibility, benefits, institutional research supports, seniority/incumbency, and course cancellations. For their part, separate bargaining unit faculty associations had, on average, superior provisions related to contract notice, infrastructural access, collegial governance, and professional expenses. All-in faculty associations had, on average, the best collective agreement provisions relating to conversion (CUPE 3903 notwithstanding). This latter finding is important because sessional interviewees identified conversion as the most important issue they face.

However, bargaining unit structures seem to have less of an impact than many of the practitioners interviewed as part of this research had assumed.

116. BUFA member, confidential interview, 29 May 2019.

117. BUFA member, confidential interview, 19 June 2019.

118. BUFA member, confidential interview, 24 June 2019. 
The vast majority of full-time faculty interviewees felt strongly that an all-in structure produced or would produce superior outcomes for sessionals, both because of the superior bargaining power it would afford and because of the greater ability to prevent whipsawing by having all academic workers in a common organization. It is not clear, however, that our quantitative findings support this view. This is in part because the all-in model does not eliminate the need for the faculty association to internally balance the interests of both groups - a challenging task given that tenured faculty and sessional instructors are often viewed as occupying opposite ends of a rigid hierarchy of academic labour on university campuses. While all-in models provide the opportunity for members to develop broader identifications and forms of solidarity, this is not guaranteed, and whether sessional interests are prioritized is a matter of political choice, not bargaining structure per se.

Sessional interviewees offered a greater mix of opinions on the perceived benefits of different bargaining unit structures. Among this group, we also detected a grass-is-always-greener effect, seemingly stemming from frustration with the inability of any of the existing models to produce meaningful job security provisions. However, in most cases, workers do not get to choose their bargaining structures. Modifying these structures, while technically possible, is very difficult in most instances given the legal context. Moreover, bargaining unit structures also are the product of and reproduce particular identities, shared understandings of a union's purpose, and definitions of members' shared or distinct interests, all of which take time to alter.

Another significant limitation of all the bargaining models explored in these case studies is that they silo the negotiation process at the level of the university, thus frustrating attempts to coordinate meaningfully at a provincial level to push, beyond the defensive, for sessional contract faculty priorities. As a result, the prospects, challenges, and opportunities for multi-union sectorwide strategy, coordination, and collaboration should inform future research in this area. As long as the collective bargaining regime in the university sector remains fragmented, breakthroughs are likely to be few and far between and individual university administrations are much better positioned to maintain the status quo even in the face of localized militancy. Should unions in the university sector seek to move to less fragmented forms of representation, whether at the university or the provincial level, more than anything they will need to confront deeply held beliefs about the nature of academic work and those who perform it.

This article draws on research supported by the Social Sciences and Humanities Research Council. The authors would like to thank Shannon Miller for her research assistance in constructing the database upon which the quantitative analysis is based. 